\title{
Water Quality Assessment of Ahoada River and its Suitability for Use
}

\author{
${ }^{1}$ A. Kalagbor Ihesinachi, ${ }^{2} \mathrm{U}$. Ene Godslove and ${ }^{3}$ Bale Dennis \\ ${ }^{1}$ Research and Development Centre, Ken Saro-Wiwa Polytechnic P.M.B. 20, Bori Rivers State, \\ ${ }^{2}$ Department of Science Laboratory Technology, \\ ${ }^{3}$ Department of Computer Science, School of Applied Sciences, Ken Saro-Wiwa Polytechnic P.M.B. 20, Bori Rivers State, Nigeria
}

\section{Correspondence}

A. Kalagbor Ihesinachi, Research and Development Centre, Ken Saro-Wiwa Polytechnic P.M.B. 20, Bori Rivers State, Nigeria, Tel.: +234803 309 8983

Received: May 10, 2020

Accepted: July 15, 2020

Published online: November 25, 2020

\section{Abstract}

The present study aims at examining some of the physical, chemical and biological characteristics of this river and the heavy metal content to determine its water quality and its suitability for both domestic and industrial use using the Weighted Arithmetic Water Quality Index method (WAWQI). Water quality assessment of the Ahoada River was carried out by collecting water samples from three different points on the river course and analyzed for some physicochemical parameters, microbial load and heavy metals content. The parameters analyzed include temperature, $\mathrm{pH}$, turbidity and electrical conductivity. Others were Chemical Oxygen Demand (COD), Biochemical Oxygen Demand (BOD), Dissolved Oxygen (DO), Total Solid (TS), Total Dissolved Solid (TDS) and bacterial load. These parameters were analyzed using recommended standard methods. The cations and anions analyzed were $\mathrm{Ca}^{2+}, \mathrm{Mg}^{2+}$, Chloride $\left(\mathrm{Cl}^{-}\right)$, Nitrate $\left(\mathrm{NO}_{3}{ }^{-}\right)$and Phosphate $\left(\mathrm{PO}_{4}{ }^{3-}\right)$. The heavy metals analysis was done using AAS. These were Chromium (Cr), Copper $(\mathrm{Cu})$, Cobolt $(\mathrm{Co})$, Nickel (Ni), Lead (Pb), Iron (Fe), Cadmium (Cd), Zinc (Zn) and Manganese (Mn). The sampling for this study was in 3 months (July, August and September). The analysis showed that $\mathrm{Fe}, \mathrm{Cd}, \mathrm{Zn} \mathrm{Cr}, \mathrm{Cu}, \mathrm{Co}, \mathrm{Ni}$ and $\mathrm{Mn}$ were not detected except $\mathrm{Pb}$ whose mean concentration value was $0.13 \mathrm{mg} / \mathrm{L}$. Most of the parameters measured were within acceptable limits of World Health Organization (WHO) standard. The microbial pollution, DO and electrical conductivity were higher than the recommended level set by WHO. Assessment of this river was done using the Weighted Arithmetic Water Quality Index (WA WQI) method. The WQI value obtained was 97.02. This rates the river as having very poor water quality thus unsuitable for drinking and domestic purpose.

Keywords: Ahoada river, heavy metals, microbial analysis, physicochemical parameters, water quality index, weighted arithmetic

\section{INTRODUCTION}

Freshwater ecosystems exhibit high natural variability in their physical and chemical properties due to differences in geology and climate. They are more susceptible to anthropogenic influences than they are in a consistent and stable marine environment. The discharge of pollutants such as commercial chemicals,

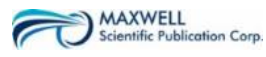

(C) The Author(s) 2020. This article is licensed under a Creative Commons Attribution 4.0 International License, which permits use, sharing, adaptation, distribution and reproduction in any medium or format, as long as you give appropriate credit to the original author(s) and the source, provide a link to the Creative Commons license, and indicate if changes were made. The images or other third-party material in this article are included in the article's Creative Commons license, unless indicated otherwise in a credit line to the material. If material is not included in the article's Creative Commons license and your intended use is not permitted by statutory regulation or exceeds the permitted use, you will need to obtain permission directly from the copyright holder. To view a copy of this license, visit http://creativecommons.org/ licenses/by/4.0/. 
industrial and agricultural wastes into the aquatic environment has led to very serious problems and various deleterious effects on aquatic organisms. As a result of the contamination of fresh water, these pollutants accumulate in the fishes and other aquatic organisms in the food chain (Hammer, 2004; Mohamed, 2009). Human and economic developments are dependent on water to a large extent. It is imperative that there should be sufficient supply of safe fresh water (Ayobahan et al., 2014). Some African countries have recorded a good number of water related diseases, especially Nigeria and this has been found to affect basic human development (FAO, 2007). Lack of adequate water for domestic, irrigation and other purposes in rural and urban centers is one of the challenging problems in Nigeria today. Access to good adequate water is very essential to health and any sustainable development. All human usage of water either for drinking, irrigation, recreation and industrial processes has some quality criteria requirements to make it acceptable. This quality requirement can be addressed in terms of physicochemical properties of such water (Maitera et al., 2010). The impact of urbanization and human activities on surface water quality has received a considerable amount of attention in the recent times. Stormwater runoff carries pollutants such as dirt, chemicals and fertilizers directly into streams and rivers where they seriously harm water quality (Wood and Bernknopf, 2003). These activities therefore, affect the physical process of river growth, modify streams structure and further influence the functions of the river system. Management and disposal of industrial wastes is a major problem in Nigeria. The industries located by the river banks use them as open sewers for their effluents. The Ahoada River is the major source of drinking for the natives; it is used for both agricultural activities and domestic purposes. Swimming and dredging activities take place in this river as well. Recently, the river is getting deeper due to dredging; it is no longer used for drinking and fishing activities, it is also polluted with a lot of organic matters and other pollutants.

\section{MATERIALS AND METHODS}

Chemicals and reagents: The chemicals and reagents used for this study were analytical grade.

Sample collection: The water samples for this study were collected from three different points (upstream, mid-stream and downstream) far away from each other for a period of 3 months (July-September). Samples were collected in $1 \mathrm{~L}$ plastic containers properly cleansed with distilled water before use. Collection was done by careful immersion of the sample containers into the river and the containers were corked right inside the river to avoid air bubbles.
Methods of analysis: The $\mathrm{pH}$ was determined in situ using a $\mathrm{pH}$ meter which was standardized using the $\mathrm{pH}$ buffers provided. The readings were taken in triplicates by immersing the electrode in the water. Temperature and conductivity measurements were carried out at all the sampling sites using Hanna hand-held instruments (HI 9813-6 and EC 215 respectively). Turbidity was measured using a turbidity meter (Xinrui WGZ 1B). The average of all the measurements was recorded. For the other parameters, they were determined in the laboratory according to APHA (1998) procedures for water and waste water. The microbial assessment was carried out as colony count $/ 100 \mathrm{~mL}$. The concentrations of heavy metals; $\mathrm{Cr}, \mathrm{Cu}, \mathrm{Co}, \mathrm{Cd}, \mathrm{Fe}, \mathrm{Ni}, \mathrm{Mn}, \mathrm{Fe}$ and $\mathrm{Pb}$ were determined by Atomic Absorption Spectrophotometer (AAS) measurements. The values obtained for all the parameters studied were compared against WHO (2011) standards.

Weighted arithmetic WQI calculations: This method classifies the water quality according to the degree of purity. This is achieved by using data collected from various water quality variables (Shweta et al., 2013) and incorporating this into the calculations thereby reflecting the composite influence of different parameters.

The following mathematical equation is used:

$$
W Q I=\frac{\sum Q_{n} W_{n}}{\sum W_{n}}
$$

$\mathrm{Q}_{\mathrm{n}}$ : The quality rating scale for each parameter

$\mathrm{W}_{\mathrm{n}}$ : The unit weight for each water quality parameter:

$$
Q_{n}=100\left[\frac{V_{n}-V_{o}}{s_{n}-V_{o}}\right]
$$

$\mathrm{V}_{\mathrm{n}}=$ Observed value

$\mathrm{V}_{\mathrm{o}}=$ The ideal value of this parameter in pure water

$\mathrm{V}_{\mathrm{o}}=0($ except $\mathrm{pH}=7.0$ and $\mathrm{DO}=14.6 \mathrm{mg} / \mathrm{L})$

$\mathrm{S}_{\mathrm{n}}=$ The recommended standard value of a parameter by WHO:

$$
W_{n}=\frac{K}{S_{n}}
$$

where,

$\mathrm{K}=1$

The rating of water quality according to this WQI is given in Table 1.

\begin{tabular}{lll}
\multicolumn{2}{l}{ Table 1: WAWQI water quality rating } \\
\hline WQI value & Rating of water quality & Grading \\
\hline$\leq 25$ & Excellent water quality & $\mathrm{A}$ \\
$26-50$ & Good water quality & $\mathrm{B}$ \\
$51-75$ & Poor water quality & $\mathrm{C}$ \\
$76-100$ & Very poor water quality & $\mathrm{D}$ \\
Above 100 & Unsuitable for drinking purpose & $\mathrm{E}$ \\
\hline
\end{tabular}

Shweta et al. (2013) 
Table 2: Physicochemical parameters of Ahoada river showing average readings from the sampling points

\begin{tabular}{|c|c|c|c|c|c|c|c|c|}
\hline Months & $\mathrm{pH}$ & Temp. $\left({ }^{\circ} \mathrm{C}\right)$ & $\begin{array}{l}\text { Turbid } \\
\text { (NTU) }\end{array}$ & $\begin{array}{l}\text { Cond. } \\
(\mu \mathrm{sec} / \mathrm{cm})\end{array}$ & $\mathrm{DO}(\mathrm{mg} / \mathrm{L})$ & $\begin{array}{l}\text { BOD } \\
(\mathrm{mg} / \mathrm{L})\end{array}$ & $\mathrm{COD}(\mathrm{mg} / \mathrm{L})$ & $\mathrm{TS}(\mathrm{mg} / \mathrm{L})$ \\
\hline July 1 & 6.1 & 28.1 & 1.2 & 140 & 20.1 & 5.6 & 30.4 & 0.2 \\
\hline 2 & 5.7 & 27.8 & 0.5 & 131 & 20.0 & 5.8 & 32.0 & 0.1 \\
\hline 3 & 5.8 & 27.6 & 0.2 & 150 & 20.2 & 5.7 & 32.8 & 0.2 \\
\hline August 1 & 5.5 & 24.6 & 5.4 & 150 & 21.4 & 6.6 & 26.4 & 0.2 \\
\hline 2 & 5.2 & 24.4 & 5.4 & 150 & 22.7 & 7.0 & 24.8 & 0.2 \\
\hline 3 & 5.3 & 25.0 & 3.7 & 150 & 20.3 & 7.1 & 18.4 & 0.2 \\
\hline September 1 & 7.8 & 25.2 & 0.6 & 110 & 36.0 & 6.2 & 32.8 & 0.1 \\
\hline 2 & 7.0 & 25.6 & 0.5 & 141 & 36.1 & 6.5 & 32.0 & 0.1 \\
\hline 3 & 6.9 & 26.1 & 0.3 & 100 & 36.2 & 6.6 & 36.8 & 0.2 \\
\hline Months & $\begin{array}{l}\text { TDS } \\
(\mathrm{mg} / \mathrm{L}\end{array}$ & $\mathrm{Ca}^{2+}(\mathrm{mg} / \mathrm{L})$ & $\begin{array}{l}\mathrm{Mg}^{2+} \\
(\mathrm{mg} / \mathrm{L})\end{array}$ & $\mathrm{Cl}^{-}(\mathrm{mg} / \mathrm{L})$ & $\begin{array}{l}\mathrm{NO}_{3}^{-} \\
(\mathrm{mg} / \mathrm{L})\end{array}$ & $\begin{array}{l}\mathrm{PO}_{4}{ }^{2-} \\
(\mathrm{mg} / \mathrm{L})\end{array}$ & $\mathrm{Pb}^{2+}(\mathrm{mg} / \mathrm{L})$ & $\begin{array}{l}\text { Bacterial } \\
\text { colony } \\
(\mathrm{Cfu} / 100 \mathrm{~mL})\end{array}$ \\
\hline July 1 & 0.2 & 25.1 & 17.1 & 12.0 & 18.4 & 0.03 & 0.074 & 19 \\
\hline 2 & 0.1 & 22.3 & 15.2 & 18.2 & 20.1 & 0.02 & 0.040 & 15 \\
\hline 3 & 0.2 & 28.2 & 20.2 & 24.1 & 24.0 & 0.11 & 0.074 & 12 \\
\hline August 1 & 0.2 & 26.2 & 19.0 & 32.3 & 10.0 & 0.12 & 0.030 & 40 \\
\hline 2 & 0.1 & 25.4 & 16.3 & 28.1 & 18.2 & 0.10 & 0.072 & 42 \\
\hline 3 & 0.1 & 30.0 & 22.1 & 37.0 & 20.3 & 0.10 & 0.058 & 41 \\
\hline September 1 & 0.2 & 20.3 & 18.1 & 25.0 & 22.1 & 0.10 & 0.060 & 50 \\
\hline 2 & 0.2 & 16.2 & 10.1 & 28.1 & 24.0 & 0.11 & 0.074 & 46 \\
\hline 3 & 0.2 & 21.4 & 21.0 & 30.1 & 20.0 & 0.10 & 0.063 & 60 \\
\hline
\end{tabular}

Table 3: Mean values of water quality parameters

\begin{tabular}{|c|c|c|c|c|c|c|}
\hline Parameters & July & Aug. & Sept. & Mean & $\mathrm{CoV}(\%)$ & WHO \\
\hline$\overline{\mathrm{pH}}$ & 5.87 & 5.33 & 7.23 & $6.14 \pm 0.98$ & 15.9 & $6.5-8.5$ \\
\hline Temp. $\left({ }^{\circ} \mathrm{C}\right)$ & 27.80 & 24.60 & 25.60 & $26.00 \pm 1.64$ & 6.3 & $25-28$ \\
\hline Turbidity (NTU) & 0.63 & 4.83 & 0.46 & $1.97 \pm 2.48$ & 13.1 & $<5 \mathrm{NTU}$ \\
\hline Conductivity $(\mu \mathrm{sec} / \mathrm{cm})$ & 140 & 150 & 117 & $135.67 \pm 16.92$ & 12.5 & $250 \mu \mathrm{sec} / \mathrm{cm}$ \\
\hline $\mathrm{DO}(\mathrm{mg} / \mathrm{L})$ & 20.10 & 21.50 & 36.10 & $25.90 \pm 8.86$ & 34.2 & $6 \mathrm{mg} / \mathrm{L}$ \\
\hline $\mathrm{BOD}(\mathrm{mg} / \mathrm{L})$ & 5.70 & 6.90 & 6.43 & $6.34 \pm 0.60$ & 9.5 & $10 \mathrm{mg} / \mathrm{L}$ \\
\hline $\operatorname{COD}(\mathrm{mg} / \mathrm{L})$ & 31.70 & 23.20 & 33.90 & $29.60 \pm 5.65$ & 19.1 & $150 \mathrm{mg} / \mathrm{L}$ \\
\hline $\mathrm{TS}(\mathrm{mg} / \mathrm{L})$ & 0.16 & 0.20 & 0.20 & $0.19 \pm 0.02$ & 10.5 & $500 \mathrm{mg} / \mathrm{L}$ \\
\hline $\mathrm{TDS}(\mathrm{mg} / \mathrm{L})$ & 0.16 & 0.13 & 0.20 & $0.16 \pm 0.04$ & 25.0 & $500 \mathrm{mg} / \mathrm{L}$ \\
\hline $\mathrm{Ca}^{2+}(\mathrm{mg} / \mathrm{L})$ & 25.20 & 27.20 & 19.30 & $23.90 \pm 4.11$ & 17.2 & $200 \mathrm{mg} / \mathrm{L}$ \\
\hline $\mathrm{Mg}^{2+}(\mathrm{mg} / \mathrm{L})$ & 17.50 & 19 & 16.40 & $17.63 \pm 1.31$ & 7.4 & $150 \mathrm{mg} / \mathrm{L}$ \\
\hline $\mathrm{Cl}^{-}(\mathrm{mg} / \mathrm{L})$ & 18.30 & 32.50 & 27.70 & $26.17 \pm 7.22$ & 27.6 & $250 \mathrm{mg} / \mathrm{L}$ \\
\hline $\mathrm{NO}_{3}^{-}(\mathrm{mg} / \mathrm{L})$ & 20.80 & 16.20 & 22 & $19.67 \pm 3.06$ & 15.6 & $50 \mathrm{mg} / \mathrm{L}$ \\
\hline $\mathrm{PO}_{4}{ }^{2-}(\mathrm{mg} / \mathrm{L})$ & 0.05 & 0.11 & 0.10 & $0.09 \pm 0.03$ & 33.3 & $5 \mathrm{mg} / \mathrm{L}$ \\
\hline $\mathrm{Pb}^{2+}(\mathrm{mg} / \mathrm{L})$ & 0.06 & 0.05 & 0.07 & $0.06 \pm 0.01$ & 16.7 & $0.01 \mathrm{mg} / \mathrm{L}$ \\
\hline Bacterial colony $(\mathrm{cfu} / 100 \mathrm{~mL})$ & 15 & 41 & 52 & $36.00 \pm 19.00$ & 52.8 & $10 \mathrm{cfu} / 100 \mathrm{~mL}$ \\
\hline
\end{tabular}

\section{RESULTS AND DISCUSSION}

Results: Presented in Table 2 are the values for all the parameters studied. The mean values for each of the parameters measured are presented in Table 3 .

\section{Discussion:}

pH: The values for $\mathrm{pH}$ were slightly acidic to neutral. In the month of July, the range was 5.7-6.1 with a mean of $5.87 \pm 0.2$. The average $\mathrm{pH}$ dropped to $5.3 \pm 0.15$ in August and peaked in September from 6.9-7.8 with a mean of $7.23 \pm 0.49$.

Temp.: The temperature readings for the 3 months under study were within the acceptable limits of $25-28^{\circ} \mathrm{C}$ (WHO, 2011). The highest temperatures were recorded in July with a mean of $27.8 \pm 0.25$, followed by September readings (25.6 \pm 0.45$)$. The month of August had the least readings of $24.4-25.0^{\circ} \mathrm{C}$ with a mean of $24.7 \pm 0.31$.
Turbidity: The values obtained were within the acceptable limits of $<5$ NTU. The highest values were recorded in the month of August (3.7-5.4 NTU) with a mean value of $4.8 \mathrm{NTU} \pm 0.98$. The months of July and September had the least values of $0.63 \pm 0.51$ and $0.46 \pm 0.15$ NTU respectively. These values are confirmed by the observation noted during the period of study that the river was clear and had little debris. This could be attributed to the rainy season.

Conductivity: High conductivity values were recorded throughout the months (July-September). The values were $100-150 \mu \mathrm{sec} / \mathrm{cm}$. The average values were $140.3 \pm 9.75,150.4 \pm 0.15$ and $117.0 \pm 21.0150 \mu \mathrm{sec} / \mathrm{cm}$ for July, August and September respectively. This is expected since there is a close relationship between the salts dissolved in water and electrical conductivity. The higher the concentration of the salts, the higher the electrical conductivity. 
Table 4: Calculation of water quality index for Ahoada river using the weighted arithmetic method

\begin{tabular}{|c|c|c|c|c|c|}
\hline Parameters & $\begin{array}{l}\text { Observed mean } \\
\text { (from Table 3) }\end{array}$ & WHO & Unit weight (Wn) & Quality rating (qn) & Wnqn \\
\hline$\overline{\mathrm{pH}}$ & 6.14 & 8.5 & 0.118 & -57.037 & -6.710 \\
\hline Temp. $\left({ }^{\circ} \mathrm{C}\right)$ & 26.04 & 28 & 0.036 & 93.016 & 3.322 \\
\hline Turbidity (NTU) & 1.98 & 5 & 0.200 & 39.556 & 7.911 \\
\hline Dissolved Oxygen (DO) $\mathrm{mg} / \mathrm{L}$ & 25.89 & 6 & 0.167 & 431.481 & 71.914 \\
\hline Biological Oxygen Demand (BOD) $\mathrm{mg} / \mathrm{L}$ & 6.34 & 10 & 0.100 & 63.444 & 6.344 \\
\hline $\operatorname{COD}(\mathrm{mg} / \mathrm{L})$ & 29.60 & 150 & 0.007 & 19.733 & 0.132 \\
\hline $\mathrm{NO}_{3}^{-}(\mathrm{mg} / \mathrm{L})$ & 19.56 & 50 & 0.020 & 39.111 & 0.782 \\
\hline Chloride $\mathrm{CL}^{-}(\mathrm{mg} / \mathrm{L})$ & 26.00 & 250 & 0.004 & 10.400 & 0.042 \\
\hline $\mathrm{PO}_{4}{ }^{2-}(\mathrm{mg} / \mathrm{L})$ & 0.09 & 5 & 0.200 & 1.756 & 0.351 \\
\hline Total Solid (TS) mg/L & 0.17 & 500 & 0.002 & 0.033 & 0.000 \\
\hline Total Dissolved Solids (TDS) mg/L & 0.17 & 500 & 0.002 & 0.033 & 0.000 \\
\hline Conductivity $(\mu \mathrm{sec} / \mathrm{cm})$ & 135.91 & 250 & 0.004 & 54.364 & 0.217 \\
\hline $\mathrm{Mg}^{2+}(\mathrm{mg} / \mathrm{L})$ & 17.56 & 150 & 0.007 & 11.704 & 0.078 \\
\hline \multirow[t]{2}{*}{$\mathrm{Ca}^{2+}(\mathrm{mg} / \mathrm{L})$} & 23.67 & 200 & 0.005 & 11.833 & 0.059 \\
\hline & & & 0.870 & & 84.442 \\
\hline$W Q I=\frac{\sum Q_{n} W_{n}}{\sum W_{n}}=97.01966$ & & & & & \\
\hline
\end{tabular}

Dissolved Oxygen (DO): The values obtained were $20.1 \pm 0.10,21.5 \pm 1.20$ and $36.1 \pm 0.1 \mathrm{mg} / \mathrm{L}$ in July, August and September respectively. These values were above the acceptable limit by WHO (2011). These values were observed to be similar to those obtained for Kaani and Kpean (Kalagbor et al., 2019), Luubara Creek (Deekay et al., 2010) and Bangha stream (Nyodee, 2016). These high DO values may be as a result of various anthropogenic activities in the river.

BOD: The BOD values for the 3 months were all found to be within acceptable limits of $10 \mathrm{mg} / \mathrm{L}$. The average results were $5.7 \pm 0.10,6.9 \pm 0.26$ and $6.4 \pm 0.21 \mathrm{mg} / \mathrm{L}$ for July, August and September respectively.

COD: In the month of August, the COD values were from 18.4 to $26.4 \mathrm{mg} / \mathrm{L}$ while July and September had higher values of $30.4-32.8$ and $32.0-36.8 \mathrm{mg} / \mathrm{L}$ respectively. The mean values were $31.7 \pm 1.22$, $23.2 \pm 4.23$ and $33.9 \pm 2.57 \mathrm{mg} / \mathrm{L}$ for July, August and September respectively. These values were below the WHO acceptable limits of $150 \mathrm{mg} / \mathrm{L}$ for COD.

TS and TDS: These 2 parameters are a measure of the amount of solid materials in the water. High levels of both TS and TDS are an indication of how unfit the water is for use. The average values obtained for TS and TDS were 0.19 and $0.16 \mathrm{mg} / \mathrm{L}$ respectively. These very low values are indications of low level of pollution from organic and inorganic sources on this river especially with the sea of heavy rainfall.

The cations $\left(\mathrm{Mg}^{2+}\right.$ and $\left.\mathrm{Ca}^{2+}\right)$ and the heavy metals: The acceptable limit for these cations in water is 150 and $200 \mathrm{mg} / \mathrm{L}$ for $\mathrm{Mg}^{2+}$ and $\mathrm{Ca}^{2+}$ respectively. The presence of these ions at high levels cause hardness of water and sometimes in combination with other salts, give water an undesirable taste. However, in this study the levels of both ions are below the recommended limits. It therefore implies that there is little or no contamination from runoffs, fertilizer, rocks or other sources containing these cations. The heavy metals that were investigated include $\mathrm{Cr}, \mathrm{Cu}, \mathrm{Co}, \mathrm{Ni}, \mathrm{Fe}, \mathrm{Mn}, \mathrm{Cd}, \mathrm{Zn}$ and $\mathrm{Pb}$. All the metals were not detected in the water samples, except $\mathrm{Pb}$ at concentrations of $0.03-0.74 \mathrm{mg} / \mathrm{L}$ throughout the months of study. These values are similar to those from the studies carried out by Iyama et al. (2014) indicating that the water is contaminated by $\mathrm{Pb}$. These values are higher than the recommended value of $0.01 \mathrm{mg} / \mathrm{L}$. This data adds to the information already existing on some Nigerian waters that have been recorded with high pollution and contaminants as presented by Lawson (2011). The presence of $\mathrm{Pb}$ in this water body is unacceptable as exposure to this metal can lead to $\mathrm{Pb}$ poisoning.

The anions $\left(\mathrm{Cl}^{-}, \mathrm{NO}_{3}{ }^{-}\right.$and $\left.\mathrm{PO}_{4}{ }^{2-}\right)$ : The values obtained for these 3 anions for the period of study were below WHO acceptable limits. Chloride $\left(\mathrm{Cl}^{-}\right)$concentrations were from 18.3 to $32.5 \mathrm{mg} / \mathrm{L}$ with the highest values recorded in August while nitrate $\left(\mathrm{NO}_{3}{ }^{-}\right)$concentrations were from 16.2 to $22.0 \mathrm{mg} / \mathrm{L}$. Phosphate $\left(\mathrm{PO}_{4}{ }^{2-}\right)$ concentrations were the lowest $(0.05-0.11 \mathrm{mg} / \mathrm{L})$. These anions were found to be of no risk to this water body as their concentrations were quite low.

Bacterial analysis: Results from this analysis showed that the highest bacterial colony count was recorded in the month of September $(52 \mathrm{cfu} / 100 \mathrm{~mL})$ followed by August (41 cfu/100 mL) and July (15 cfu/100 mL). This implies that the sanitary quality of this river is very poor. The high levels of bacterial colony count are in agreement with the findings of Iyama et al. (2014). Their study showed that coliform and Total Heterotrophic Bacterial (THB) count were relatively higher during the rainy season. 
Statistical analysis: The Weighted Arithmetic (WA) method was used in evaluating the water quality of Ahoada River. A total of 16 parameters were analyzed out of which 15 were used for this evaluation. This method was employed following the result from Kalagbor et al. (2019) for similar studies where the WA method gave a better assessment of the water quality of Kaani and Kpean rivers. From the result presented in Table 4, the water quality index for Ahoada River using Eq. (1) is 97.02. This puts the water quality rating as very poor as shown in the WA weighting chart (Table 1).

\section{CONCLUSION}

Water quality index of Ahoada River was based on the analysis of various important parameters. Most of the physicochemical parameters were within WHO acceptable limits except Dissolved Oxygen (DO), Pb concentrations and bacterial load. The high values obtained for DO can be attributed to the anthropogenic activities in this river. The $\mathrm{Pb}$ levels exceeded $0.01 \mathrm{mg} / \mathrm{L}$ and this is a source of concern as exposure to this metal can lead to $\mathrm{Pb}$ poisoning. It has also been categorized as a carcinogen. The high bacterial load is an indication of feacal contamination. The results obtained were utilized to deduce the suitability of this water body for use. The WQI of 97.02 shows that the river has very poor quality rating and is therefore unfit for drinking and other domestic purposes.

\section{REFERENCES}

APHA, 1998. Standard Methods for the Examination of Water and Wastewater. Works Association and Water Environment Federation (APHA-AWWAWEF), Published by the American Public Health Association, Washington, D.C.

Ayobahan, S.U., I.M. Ezenwa, E.E. Orogun, J.E. Uriri and I.J. Wemimo, 2014. Assessment of anthropogenic activities on water quality of Benin River. J. Appl. Sci. Environ. Manage., 18: 629-636.

Deekay, S.N., J.F.N. Abowei and A.C. Chindah, 2010. Some physical and chemical parameters of Luubara creek, Ogoni land, Niger Delta, Nigeria. Res. J. Environ. Earth Sci., 2(4): 199-207.

FAO (Food and Agricultural Organization), 2007. Coping with Water Scarcity. Challenge of the Twenty-first Century. 2007 World Water Day, 22nd March, 2007. Retrieved from: http://www.fao.org/3/a-aq444e.pdf.
Hammer, M.J., 2004. Water and Wastewater Technology. 5th Edn., Practice-Hall Inc., Upper Saddle River, NJ, USA, pp: 139-141.

Iyama, W.A., O.S. Edori and S. Ikpe, 2014. Study of pollution levels in Ahoada-ihuaba Axis of Sombreiro River, Ahoada Rivers State, Nigeria. Int. Res. J. Pure Appl. Chem., 4: 378-387.

Kalagbor, I.A., V.I. Johnny and I.E. Ogbolokot, 2019. Application of national sanitation foundation and weighted arithmetic water quality indices for the assessment of Kaani and Kpean Rivers in Nigeria. Am. J. Water Resour., 7: 11-15.

Lawson, E.O., 2011. Physico-chemical parameters and heavy metal contents of water from the mangrove swamps of Lagos Lagoon, Lagos, Nigeria. Adv. Biol. Res., 5: 8-21.

Maitera, O.N., V.O. Ogugbuaja and J.T. Bariminas, 2010. An assessment of the organic pollution indicator levels of River Benue in Adamawa state, Nigeria. J. Environ. Chem. Ecotox., 2: 110-116.

Mohamed, F.A.S., 2009. Histopathological studies on Tilapia zillii and solea vulgaris from lake Qarun, Egypt. World J. Fish Mar. Sci., 1: 29-39.

Nyodee, G.T., 2016. Determination of water quality index for Bangha stream in Bangha community, rivers state, Nigeria. Sci. Ind. Tech. Edu. J., 3: 182-189.

Shweta, T., S. Bhavtosh, S. Prashant and D. Rajendra, 2013. Water quality assessment in terms of water quality index. Am. J. Water Resour., 1: 34-38.

WHO (World Health Organization), 2011. Guidelines for Drinking-water Quality. 4th Edn., NLM Classification: WA675, World Health Organization, Geneva, Switzerland, pp: 307-433.

Wood, A. and R. Bernknopf, 2003. Preliminary preview for a geographic and monitoring program project: A review of point source-nonpoint source effluent trading/offset systems in watersheds. Open File Report 03-79 2003. Retrieved from: https://pubs.usgs.gov/of/2003/of03079/Wood_OFR03-79.pdf. 